\title{
$\mathrm{CDMA}$ 모뎀을 이용한 원격 제어 및 계측 시스템 구현
}

\section{The implementation of the Remote Control and Measurement Systems using CDMA Modem}

\author{
이명의 ${ }^{*}$ \\ Myung-Eui Lee* \\ 요 약
}

본 논문에서는 $\mathrm{CDMA}$ 데이터 모뎀을 이용하여 원격에서 다양한 입출력 장치들의 상태를 계측하거나 이들을 제어하는 시스템을 설계하고 개발한다. 그리고 TCP/IP 패킷 통신과 단문자서비스(SMS) 통신방식을 이용하여 공 인 IP 주소를 갖지 않는 $\mathrm{CDMA}$ 모뎀 장치들을 위한 양방항 데이터 통신 방식을 제안한다. 설계된 원격 제어 및 계측시스템은 DCE로 Telit WM-800 모뎀과 DTE로서 Atmel AT89C51 마이크로컨트롤러를 사용하여 구현되었다. 제어 및 계측 시스템 사용자를 위한 사용자 응용 프로그램, 그리고 디지틀 입출력 장치, $\mathrm{AD} / \mathrm{DAC}, \mathrm{LCD}$, 및 온 습도 센서 등의 펌웨어 구동장치 프로그램은 보다 다양한 종류의 응용을 위하여 각각 Microsoft C 및 Keil C 언어를 사용하여 작성되었다. 본 논문에서 구현된 제어 및 계측 시스템의 실험결과는 실제 실시간 실험을 통 해, 설계된 바와 같이 사용자가 원하는 동작을 정확하게 수행하는 것을 확인하였다.

\section{Abstract}

This paper deals with the design and development of the remote control and measurement systems using CDMA(Code Division Multiple Access) data modem. We propose a bi-directional data communication link without the public IP address in CDMA modem device by the TCP/IP packet and SMS(Short Message Service) communication. The remote control and measurement systems are implemented by a Telit WM- 800 modem as DCE(Data Communication Equipment), and Atmel AT89C51 microcontroller as DTE(Data Terminal Equipment). The user application software for the control and measurement system user, and the firmware software of device drivers for peripherals such as a digital input/output device, AD/DAC(Analog to Digital/Digital to Analog Converter), LCD, and temperature/humidity sensor are written in Microsoft $\mathrm{C}$ and Keil C language respectively for further various applications. The experimental result of the proposed control and measurement systems implemented in this paper is evaluated via real-time experiments, which works well as designed.

Key words : CDMA modem, SMS, Contol, Measurement, Microcontroller

I. 서 론

유무선 통신을 이용하여 원격에서 기기의 상태나 센서 등의 입력장치를 모니터하거나, 또는 릴레이,

* 한국기술교육대학교 정보통신공학(Dept. of Information and Communication Eng., KUT)

· 제1저자 (First Author) : 이명의

· 투고일자 : 2012년 3월 9일

심사(수정)일자 : 2012년 3월 9일 (수정일자 : 2012년 4월 24일)

· 게재일자 : 2012년 4월 30일 
액튜에이터 등의 출력장치를 제어하기 위한 여러 가 지 많은 시도가 있었으며 이에 대한 연구도 최근까지 활발하게 진행되고 있다[1],[2],[3]. CDMA 모뎀을 사 용하여 무선으로 원격제어 및 계측을 수행하기 위해 서는 데이터 링크를 구성해야 하며, 2가지 종류의 통 신방식으로 회선(Circuit) 접속 및 패킷(Packet) 접속 방식이 있다. 회선접속 방식은 비교적 접속속도가 느 리고 Dial-Up Modem 접속방식으로 PSTN망 접속 및 팩스 송수신이 가능하다. 따라서 회선접속 방식은 접 속빈도가 낮고 대량의 데이터 전송에 적합하다. 반면 에 패킷접속 방식은 접속속도가 수초 정도로 아주 빠 르고 인터넷망에 접속이 가능하여 접속빈도가 많은 데이터 전송에 적합하다[4]. 따라서 패킷방식은 패킷 데이터망에 접속하여 인터넷 검색, 모바일 뱅킹, 신 용카드 조회/승인, 증권조회/체결, 현장 $\mathrm{A} / \mathrm{S}$ 업무, 원 격검침, 자동판매기, 원격제어 및 계측 등에 널리 사 용되고 있으며 패킷망에 접속 구성도는 아래 그림1 과 같다[5].

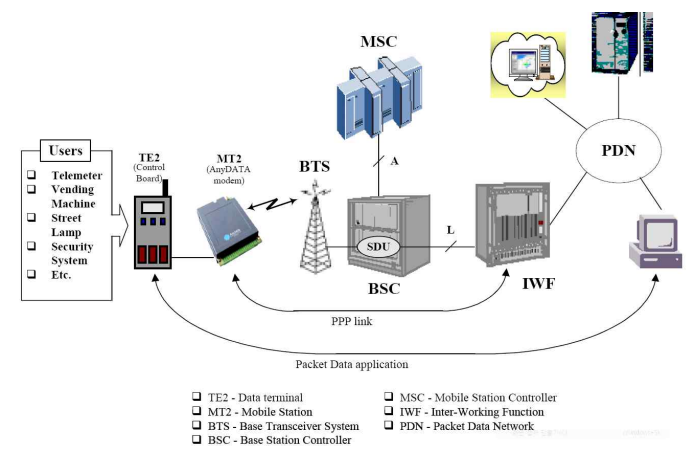

그림 1. CDMA 패킷 데이터 구성도

Fig. 1. Packet Data Network with CDMA.

따라서 본 연구에서는 원격제어 및 계측용으로 가 장 적합한 패킷방식의 무선이동통신 모뎀을 이용하여 데이터 링크를 구성하였다. 이동통신망을 사용하여 데이터 링크를 구성하기 위해서 우선 회선(Circuit)접 속 또는 패킷(Packet) 접속을 선택해야 하며, 이를 선 택하기 위해서는 사전에 AT $+\mathrm{CRM}$ 명령어를 사용하여 회선접속 또는 패킷 접속을 지정하여야 하며 회선접 속인 경우에는 $\mathrm{AT}+\mathrm{CRM}=0$ 명령을 사용하고, 패킷접 속인 경우에는 $\mathrm{AT}+\mathrm{CRM}=1$ 또는 사업자 요구에 맞는 $\mathrm{CRM}$ 값을 입력해야 하며, 이와 같이 접속된 패킷방식 의 통신전송 계층도는 다음의 그림2와 같다[5].

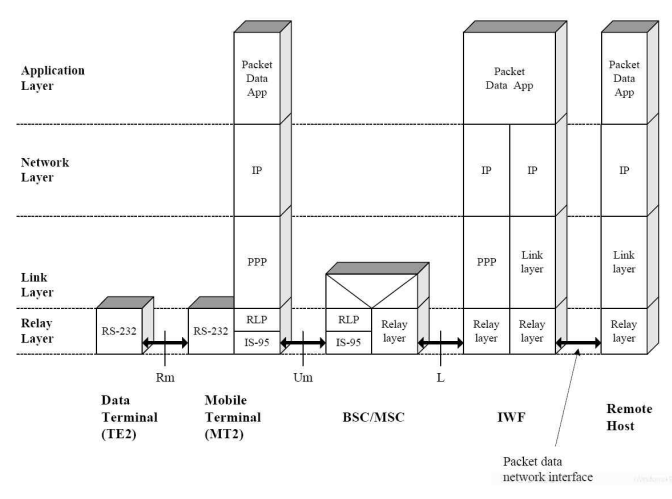

그림 2. 패킷망의 통신 계층도

Fig. 2. Communication Layer of Packet Data.

그러나 원격 제어 및 계측 장치와 이를 이용하는 사용자의 컴퓨터가 양방항 통신을 위해서는 패킷통 신 방식에 문제가 발생한다. 원격 제어 및 계측을 위 한 사용자 컴퓨터는 고정된 IP 주소를 보유하고 있기 때문에 원격 계측 데이터를 사용자 컴퓨터에 전송하 는 경우, 패킷통신을 통하여 데이터를 전송할 수 있 지만, 반대로 사용자 컴퓨터에서 원격 제어 명령을 원격 제어 및 계측 장치로 데이터를 전송할 경우에는 원격제어 및 계측 장치에서 사용되는 CDMA 모뎀의 고정 IP주소가 없기 때문에 일반적인 패킷통신 방식 을 사용할 수 없는 문제가 있다. 따라서 본 논문에서 는 이와 같은 문제를 해결하기 위한 효율적인 방안을 제시하고, 실제 시스템의 구현을 통해 전체 시스템의 원활한 동작을 확인한다.

\section{CDMA 패킷망의 데이터 링크 구성}

패킷망을 구성하여 원격 제어 및 계측을 수행하기 위한 데이터 링크 구현을 위하여 본 연구에서는 DCE(Data Communication Equipment)로 Telit社의 WM-800 CDMA 모뎀을 사용하였으며 WM-800 모뎀 은 전이중(Full-duplex) 최대 $153.6 \mathrm{Kbps}$ 의 전송속도를 갖고 있다. 본 CDMA 모뎀은 RS-232C 인터페이스 상 에서 AT Command Set을 사용하여 데이터 송수신이 가능하며, 또한 음성 인터페이스를 통한 음성통화가 가능하도록, 이를 위한 AT Command Set을 추가로 정 의하고 있다. 그리고 TIA/EIA/IS-707-A의 TE2(Terminal Equipment 2) 및 MT2(Mobile 
Termination 2)를 사용하는 Network Model을 사용하 고 있으며 그 내부 구성은 다음의 그림3과 같다[6]. 아래 그림에서와 같이 원격제어 및 계측과 같은 응용 장치들은 RS-232 인터페이스를 통해 DTE(Data Terminal Equipment)로 별도의 마이크로컨트롤러 $(\mathrm{MCU})$ 를 사용하여 구성한다. 따라서 본 연구에서는 MCS51 계열인 ATMEL社의 AT89C51을 사용하여 원 격 제어 및 계측 장치를 구성하였다.

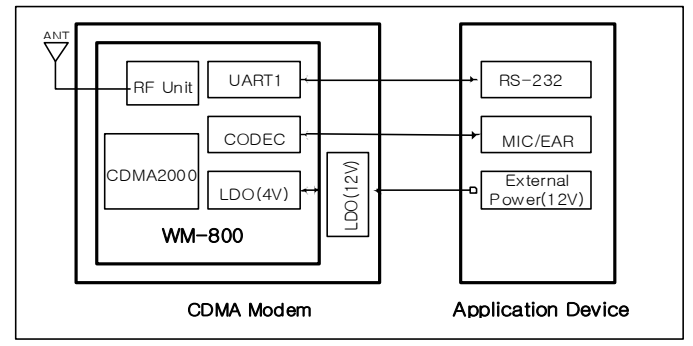

그림 3. $\mathrm{WM}-800 \mathrm{CDMA}$ 모뎀의 내부 구성도(DCE)

Fig. 3. Internal Block of WM-800 CDMA Modem.

서론에서도 지적된 바와 같이 사용자 컴퓨터와 원 격 제어 및 계측 장치가 양방향 통신을 하기 위해서 는 다음과 같은 문제가 발생한다. $\mathrm{CDMA}$ 통신 모뎀 은 우리가 일상생활에서 사용하는 휴대전화 단말기 와 같이 전화번호를 할당받지만 TCP/IP 패킷 통신을 위한 고정 IP 주소를 갖고 있지 않기 때문에, 이 문제 를 해결하기 위해서는 아래와 같이 2가지 방법이 있 다. 첫 번째는 회선접속방식을 사용하는 방법으로, 이와 같은 방식을 사용하기 위해서 또 다른 하나의 $\mathrm{CMDA}$ 모뎀이 사용자 컴퓨터에 연결되어 사용자 컴 퓨터에서 원격 제어 및 계측장치의 CDMA 모뎀 (DCE)에 전화번호로 회선접속을 하는 방식이다. 이 와 같은 방법에서는 2 개의 $\mathrm{CDMA}$ 모뎀이 요구되며, 또한 패킷방식에 비해서 접속속도가 늦은 단점이 존 재한다. 따라서 본 논문에서 제시하는 방식으로, 두 번째는 SMS 서버를 이용하여 별도의 또 다른 CMDA 모뎀이 없이도 SMS 문제 메시지를 원격 장치 (MCS51)로 전송하는 방식이다. 본 연구에서는 별도 의 또 다른 $\mathrm{CDMA}$ 모뎀이 필요 없도록 SMS 방식을 이용하여 양방향 통신을 구성하였으며 전체 시스템 의 구성은 아래 그림4와 같다.

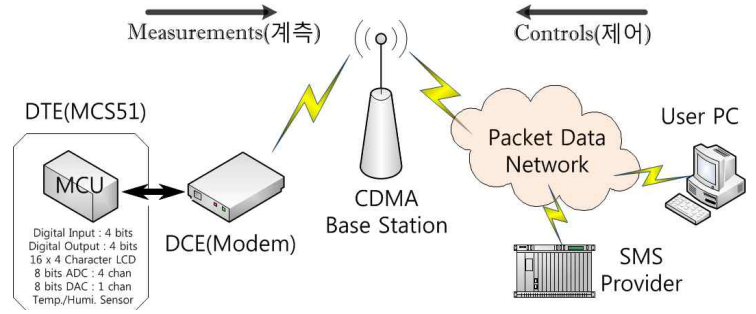

그림 4. 원격 제어 및 계측 시스템 전체 구성도

Fig. 4. Remote Control and Measurement Systems.

그림4에서와 같이 원격장치(DTE)에서의 계측 데 이터는 패킷망을 이용하여 $\mathrm{CDMA}$ 모뎀을 통해 고정 된 IP주소를 갖는 사용자 컴퓨터로 전송되며, 그리고 사용자 컴퓨터로부터의 제어 명령 데이터는 CDMA 모뎀(DCE)가 보유하고 있는 단말기 번호를 통하여 $\mathrm{SMS}$ 로 전송된다. 따라서 MCS51에서는 사용자 컴퓨 터로부터의 문자메세지 명령을 해독하여 사용자 명 령에 따른 동작을 수행한다. 이에 대한 더욱 상세한 내용은 원격 제어 및 계측 시스템의 소프트웨어 부분 에서 설명한다.

기본적으로 DTE(MCS51 보드)는 항상 모뎀(DCE) 의 호연결상태를 정확하게 알고 있어야 하며, 모뎀의 상태는 모뎀이 통보하는 "CONNECT"/"NO CARR IER"로 알 수 있다. AT 명령으로 호연결을 시도하여 호가 연결되면, 모뎀은 호연결 상태(Connected State) 로 전이되고, 이를 "CONNECT"통보로 응답한다. 반 면에 여러 가지 다양한 조건에 의해 호가 해제되면 모뎀은 "NO CARRIER"통보 후, 해제상태(Disconnec ted State)로 되며 이에 대한 호연결 상태도는 아래 그 림5와 같다.

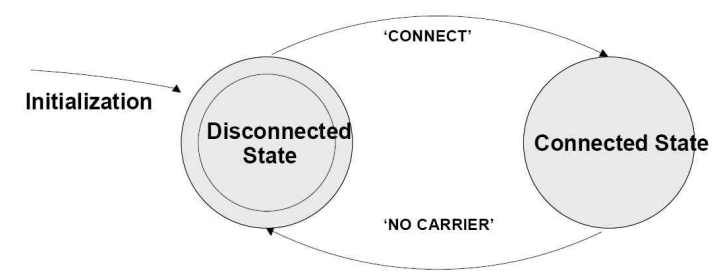

그림 5. $\mathrm{CDMA}$ 모뎀의 호연결 상태도

Fig. 5. State Diagram of CDMA Call connection.

그리고 호를 시도할 때에는 반드시 "CONNECT/ NO CARRIER/NO DIALTONE"과 같은 통보를 수신 한 후에 다음 명령을 수행해야 하며, 반드시 최대 30 초를 대기하도록 프로그램을 설계해야 한다[6]. 
III. 원격 제어 및 계측 시스템의 구현

\section{3-1 하드웨어 시스템 설계 및 구현}

원격제어 및 계측 시스템에 사용되는 $\mathrm{CDMA}$ 모뎀 과의 RS-232 통신으로 패킷망에 접속하기 위해서는 별도의 $\mathrm{MCU}$ 가 필요하며 본 과제에서는 이를 위하여 ATMEL社의 AT89C51ED2를 사용하였다. AT89C51 은 MCS51 호환으로 내부에 On-chip 64K bytes Flash Program 메모리, 내부에 256 Bytes Scratch Pad RAM 이외에 On-chip 1792 bytes Data 메모리, 그리고 내부 에 On-chip $2 \mathrm{~K}$ bytes EEPROM 메모리를 갖고 있다. 다양한 입출력 처리를 가상하여 출력장치로 $16 \times 4$ Line $\mathrm{LCD} * 1$, 디지털 입력장치로 DIP Switch * 4, 디 지털 출력장치로 $\mathrm{LED} * 4, \mathrm{I} 2 \mathrm{C}$ 방식의 온습도센서 * 1, 그리고 PCF8591* 1 (8-bit A/D and D/A converter) 을 사용하였으며 구성도는 아래 그림6과 같다[7].

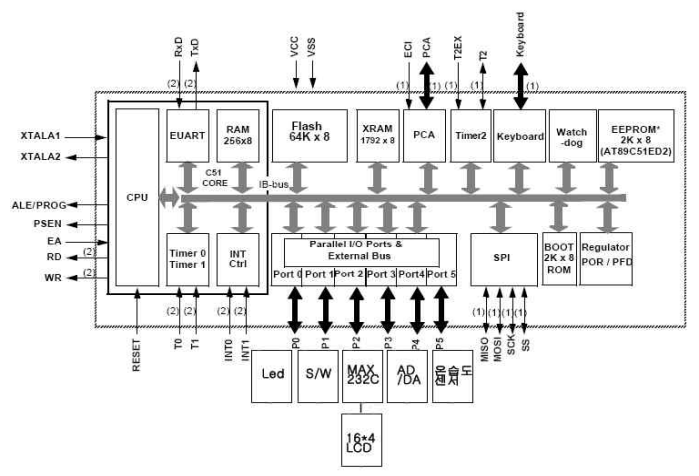

그림 6. 원격제어 및 계측 시스템의 하드웨어 구성도

Fig. 6. Hardware Block Diagram of Implemented Systems.

각종 입출력장치의 데이터는 원격 제어 및 계측을 위한 사용자 컴퓨터 화면에서 실시간으로 모니터될 수 있으며 분석될 수 있도록 한다. 모든 프로그램은 $\mathrm{C}$ 컴파일러를 사용하여 $\mathrm{C}$ 언어로 작성되기 때문에 추 후에 어떠한 응용에도 용이하게 포팅되어, 본 연구에 서 개발된 통신 프로그램의 소스코드를 그대로 거의 수정 없이 사용할 수 있다. 이와 같이 구성된 하드웨 어 시스템의 상세 회로도는 생략하며 사진은 그림7 과 같다. 아래 사진에서 좌측하단이 본 논문에서 사 용된 모뎀이고 우측이 구현된 하드웨어이다.

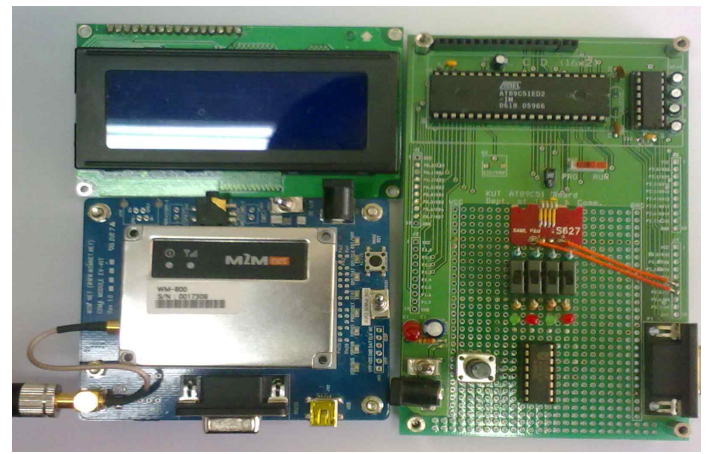

그림 7. 원격제어 및 계측 장치의 하드웨어 전체 사진

Fig. 7. Pictures of CDMA Modem and Hardware.

\section{3-2 원격제어 및 계측 시스템의 소프트웨어 구성}

원격제어 및 계측 시스템의 소프트웨어는 크게 MCS51(DTE) 부분의 프로그램과 원격 제어 및 계측 을 위한 사용자 컴퓨터의 응용 프로그램이 있으며 아 래 그림 8과 같다. MCS51에서는 CDMA 모뎀을 제어 하는 프로그램과 디지틀 입출력을 포함하여 각종 입 출력 장치를 제어하는 프로그램이 있다. 그리고 사용 자 컴퓨터에서 패킷망을 통하여 CDMA 모뎀과 통신 하는 프로그램과 사용자가 원격장치의 여러 가지 입 출력 장치를 제어할 수 있는 사용자 프로그램이 있 다.

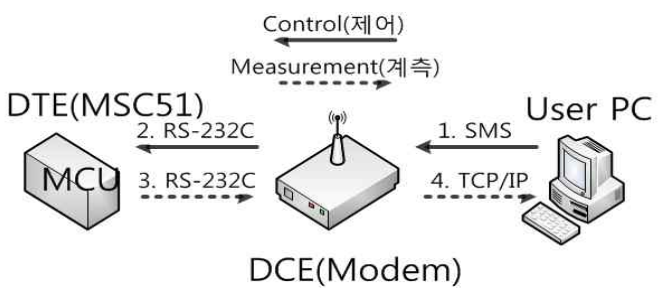

그림 8. 원격제어 및 계측 시스템의 양방향 통신구성 Fig. 8. Bi-directional Communication of Implemented Systems.

따라서 위의 그림에서와 같이, 우선 사용자 컴퓨 터의 응용프로그램에서 원격장치의 원격지 $\mathrm{CDMA}$ 모뎀으로 제어문자가 담긴 $\mathrm{SMS}$ 를 보내면 모뎀은 원 격제어 및 계측장치의 MCS51과 RS-232C 시리얼통 신을 통해 SMS가 도착했음을 알리고 원격제어 및 계 측장치의 MCS51은 모뎀에게 AT command와 함께 현재의 원격제어 및 계측 장치의 상태 정보가 담긴 데이터를 전송한다. 이와 같이 전송되는 원격제어 및 계측 장치의 데이터 형식은 2-digit Hex code 형태로 구성되었으며, 전송되는 정보를 TCP/IP 패킷통신 방 
식을 통해 원격지 사용자 컴퓨터에 전송한다. 위의 그림에서 1 번과 4 번은 Visual $\mathrm{C}++$ 언어로 제어프로그 램을 작성하였으며 2 번과 3 번은 Keil C 언어로 제어 프로그램을 작성하였다[8].

\section{3-3 원격제어 및 계측장치(MCS51)의 통신 프} 로그램

원격제어 및 계측 장치의 MCS51 프로그램 시작 시, 우선 $\mathrm{CDMA}$ 모뎀과의 통신을 위하여 MCS51의 Baud rate를 $115200 \mathrm{bps}$ 로 설정하고 LCD 초기화를 수 행한다. 그리고 notTest() 함수를 실행해 CDMA 모뎀 에 'atv0' 란 명령어를 전송한다. 이 명령어는 CDMA 모뎀이 수신한 명령어에 대한 에코(Test)를 MCS51보 드에 다시 보내지 않도록 설정하는 명령어이다. 그리 고 MCS51 보드는 CDMA 모뎀으로부터 명령어 응답 을 수신할 때까지 대기한다. 원격제어 및 계측 서버 $\mathrm{PC}$ 로부터 $\mathrm{CMDA}$ 모뎀에 원격제어 및 계측 서버 사 용자의 명령어가 담긴 SMS가 도착할 경우 $\mathrm{CDMA}$ 모 뎀은 MCS51보드에 '\$008:0' 이란 Notification을 시리 얼 통신을 통해 전송한다. 이와 같은 통보는 원격제 어 및 계측 서버 컴퓨터로부터 명령어가 담긴 문자가 도착했음을 알리는 신호이다. 따라서 MCS51보드는 '\$008:0' 문자가 송신되었는지 계속해서 검사 후, 맞 을 경우 모뎀에 'at\$smsmt=1?' 이란 AT command를 전송한다. 이는 수신메시지에 어떤 내용이 수신되었 는지 확인하기 위한 AT command이며 그 수행 절차 는 아래 그림9와 같다.

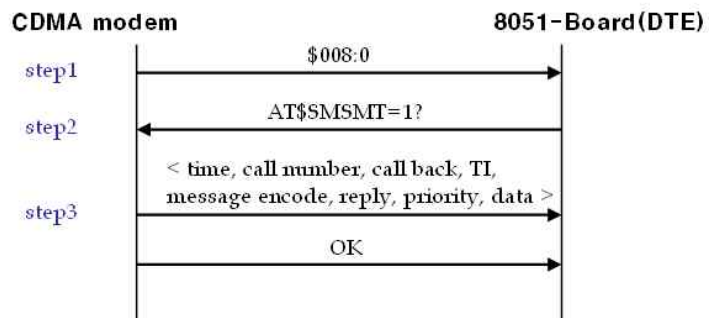

그림 9. 사용자 컴퓨터로 부터의 명령(SMS) 확인 절차

Fig. 9. SMS Call Procedure between DTE and DCE.

이와 같은 명령어를 수신한 CDMA 모뎀은 MCS51 보드에 SMS 메시지를 수신한 시간 + 발신 전화번호 + 원격제어 및 계측 서버 $\mathrm{PC}$ 로부터 온 메시지 등의 내용을 전송하며 명령확인 절차와 상세한 메시지의 구조는 그림10과 같다.

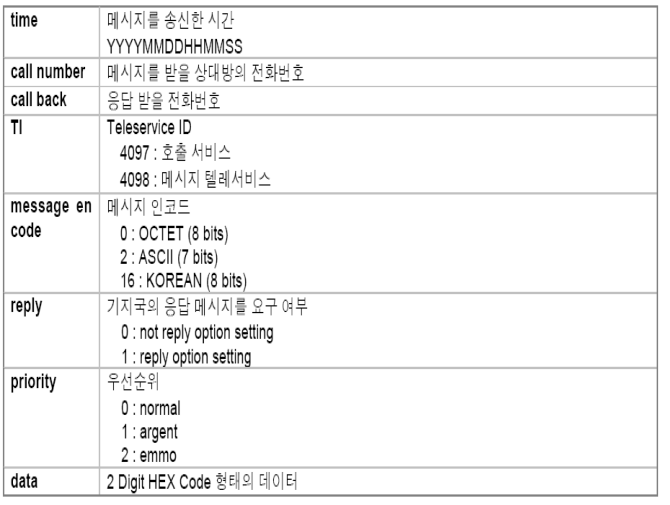

그림 10. SMS 전송문자의 내부 구조

Fig. 10. Internal Structure of SMS Data.

원격제어 및 계측 서버 컴퓨터에서 전송된 명령은 원격제어 및 계측 장치의 $\mathrm{CDMA}$ 모뎀을 통하여 SMS 메시지를 MCS51 보드에 전달한다. 전달된 데이 터는 Hex code 형식의 <data> 부분만을 추출하여 버 퍼에 저장한다. <data> 부분에는 제어명령의 종류, 제 어의 내용, 원격제어 및 계측 서버 PC의 IP 주소와 포 트넘버 등의 정보가 포함되어 있다. MCS51 보드는 버퍼에 저장된 데이터를 분석하여 $\mathrm{LCD}, \mathrm{LED}$, DIP Switch, 온습도센서, $\mathrm{ADC} / \mathrm{DAC}$ 에 관한 명령인가를 확인 후 해당 함수를 호출한다. 여기서 $\mathrm{LCD}, \mathrm{LED}$, $\mathrm{DAC}$ 에 대한 출력장치인 'write' 명령의 경우, 해당 출 력기능을 MCS51 보드에서 수행하고 종료하게 된다. 그 외에, $\mathrm{DIP} \mathrm{S} / \mathrm{W}$, 온습도센서, $\mathrm{ADC}$ 에 대한 입력장 치인 'read' 명령의 경우, 해당 입력상태 정보를 입력 한 후, 이 입력결과를 CDMA 모뎀을 통하여 다시 사 용자 컴퓨터로 전송하며, 아래 그림11과 같은 순서에 따라 TCP/IP 패킷망을 이용하여 데이터를 전송한다.

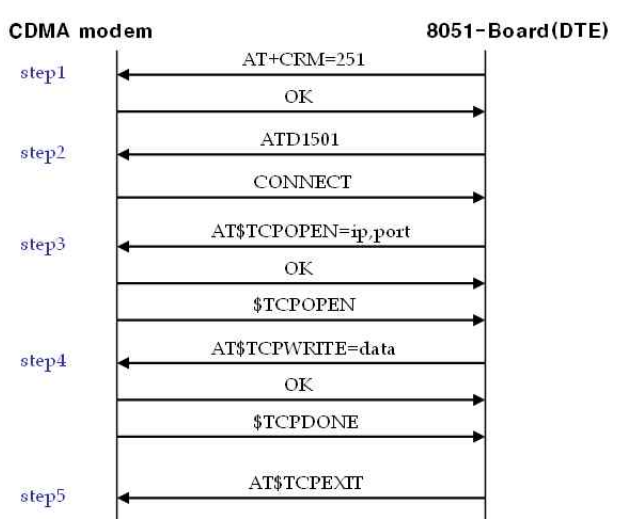

그림 11. 입출력장치와 사용자 컴퓨터와의 통신절차 Fig. 11. TCP/IP Procedure between DCE and DTE.

패킷망을 이용하여 원격제어 및 계측 서버 컴퓨터 
에 데이터를 전송하기 위해서 MCS51 보드에서는 우 선 'at $+\mathrm{crm}=251$ '란 AT command를 CDMA 모뎀에 전 송한다. 이 명령은 모뎀의 내장 TCP/IP 기능을 사용 하도록 설정하는 초기 명령어로, $\mathrm{CDMA}$ 모뎀은 전원 을 $\mathrm{OFF}$ 하게 되면 설정 값을 초기화 하므로 $\mathrm{TCP} / \mathrm{IP}$ 연결 이전에 $\mathrm{CDMA}$ 모뎀에 반드시 가장 먼저 전송해 야 하는 명령이다. 그 다음으로 'ATD1501'이란 AT command를 모뎀에 전송한다. 이는 패킷접속명령으 로, 그 후 모뎀으로부터 'CONNECT' 란 패킷접속성 공 메시지를 받으면 보드는 'at\$tcpopen= ip,port' 형식 의 AT command를 보낸다. 이 명령구문에 원격제어 및 계측 서버 PC의 IP 주소와 Port 번호를 동시에 전 송한다. 만약 $\mathrm{CDMA}$ 모뎀과 원격제어 및 계측 서버 와 성공적으로 TCP 접속이 완료되면 '\$TCPOPEN' 이 란 TCP 접속 성공 메시지로 MCS51 보드에 응답한 다. 그러면 MCS51 보드에서는 원격제어 및 계측 서 버에 전송할 데이터를 송신하기 위해서 'at\$tcpwrite=data' 형식의 AT command를 전송한다. 여 기서 MCS51 보드는 명령어의 data 부분에 원격제어 및 계측 서버에서 요청한 DIP S/W, 온습도센서, $\mathrm{ADC}$ 등에서 입력한 정보를 hex code 형식으로 변환하여 전송 하게 된다. 그 후 command 전송이 성공하게 되 면 모뎀은 \$TCPS ENDDONE 이란 데이터 전송완료 통보 메시지를 보내게 된다. 그 다음 MCS51 보드는 $\mathrm{TCP}$ 연결 호 단절을 위해서 'at\$tcp exit' 란 AT command를 전송 후 종료하게 된다[6].

\section{3-4 사용자 컴퓨터의 통신 프로그램}

사용자 컴퓨터와 원격 제어 및 계측 장치와의 통 신은 SMS 서비스 업체에서 제공하는 ezSMS Component API를 이용하여 프로그램 하였다. SMS 메시지 전송 API는 ezSMS 서버에 로그인 하여 문자 전송, 예약, 그리고 전송 내역 확인 등의 업무를 수행 할 수 있도록 구성되어 있다. ezSMS Component는 Component Object Model $(\mathrm{COM})$ 을 기반으로 제작 되 었으며 이를 지원하는 프로그래밍 언어, 스크립트, VBA(Visual Basic for Application) 등에서 사용할 수 있다. 이에 본 프로그램은 $\mathrm{COM}$ 을 지원하는 Micro soft Visual C++ 언어에 기반 하여 작성되었으며 ez SMSComponent 객체는 표준 $\mathrm{COM}$ 생성 메서드를 통
해 생성하였다. 로그인 기능 외에도 문자 전송, 잔여 메시지 전송횟수 확인 등의 작업 역시 ezSMS Component의 SMS 객체를 생성하여 프로그램 할 수 있다.

원격제어 및 계측 장치의 $\mathrm{CDMA}$ 모뎀으로의 문자 전송에는 ezSMSComponent의 SMS 객체를 생성하는 과정이 필요하며 지금부터 ezSMSComponent를 이용 하여 문자를 전송하는 과정을 설명한다. 우선 CoInitialize(Windows API) 등의 함수로 $\mathrm{COM}$ 을 초기 화 한 후 SMS 객체를 생성한다. 그리고 ISMS::Servic eCode 속성에 SMS 서비스 업체에서 개인 사용자에 게 제공한 컴포넌트 서비스 코드를 설정한다. 그 후 사용자가 명령을 내리도록 기다리면서 문자를 전송 하라고 명령하면 ISMS::SendSMS 메서드를 사용하여 문자를 전송한다. 만약 ISMS::SendSMS 메서드가 EZSMS_E_LOGINFAIL(로그인 상태가 아니거나 로 그인 정보가 잘못 됨)를 반환하게 되면 ISMS::Login 메서드를 통해 ezSMS Server에 로그인 하며 이와 같 은 절차는 아래 그림12와 같다.

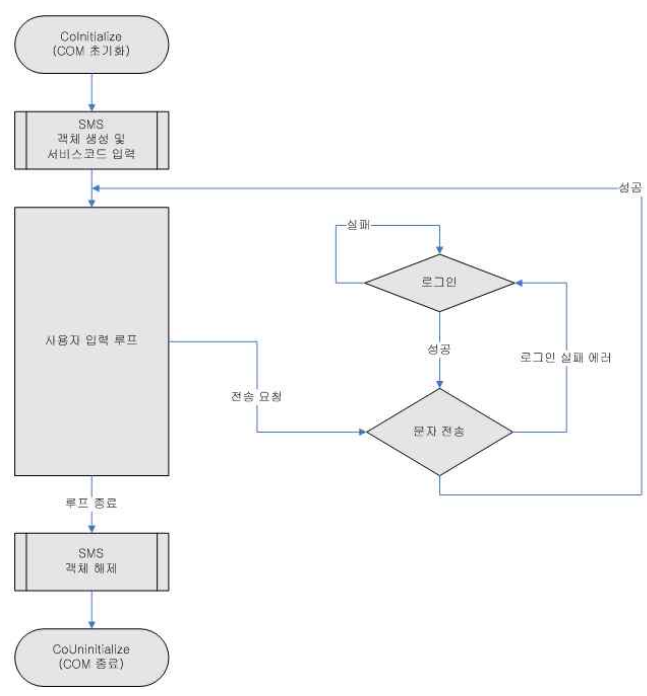

그림 12. ezSMS Component 이용 과정

Fig. 12. ezSMS Component Utilization Flow Chart.

로그인 과정은 단지 아이디와 패스워드 그리고 서 비스 코드를 확인하는 절차일 뿐이며 서버는 인증이 확인되면 클라이언트에게 결과 값을 알려주며, 이와 동시에 연결을 종료시킨다. 이는 HTTP 연결과 비슷 하게, 응답을 받은 즉시 소켓 연결을 해제한다. 문자 전송 외에 전송 내역 요청(ISMS::RequestLog)이나 예 
약 취소(ISMS::CancelRese rvation) 등의 메서드를 호 출하여 EZSMS_E_LOGIN FAIL를 반환받게 되면 위 흐름도의 전송 메커니즘과 마찬가지로 다시 로그인 을 수행해야 한다. 처음에 로그인 성공 후 웹 사이트 에서 사용자의 패스워드를 바꾸게 되면 문자 전송, 로그 요청 등 특정 메서드를 호출하면서 로그인 실패 가 일어날 수 있다. 더 이상 컴포넌트를 사용하지 않 으면, CoUninitialize (Windows API) 등의 함수로 $\mathrm{COM}$ 사용을 해제한다. ISMS::SendSMS 문자 전송 구문은 $\mathrm{C}++$ 프로그램에 나타나 있으며 다음과 같은 형식을 갖는다.

\section{HRESULT SendSMS( \\ BSTR ReturnPhone, \\ IReceivers* pReceivers, \\ ISendResults** ppSendResults);}

ReturnPhone은 회신 번호를 나타내고 pReceivers는 수신자 휴대폰과 전송 메시지를 포함하는 수신자 정 보 목록을 나타내고 ppSendResults는 접수 결과를 저 장할 ISendResults 인터페이스의 포인터의 포인터를 나타내는 매개변수 이다. 이 반환 값이 NULL이면 전 송 결과를 반환하지 않는다[9].

\section{3-5 사용자 응용 프로그램}

원격 제어 및 계측을 위한 사용자 컴퓨터에서 실 행되는 사용자 프로그램은 MS Visual Studio의 C++ 를 사용하여 작성하였다. 이와 같은 사용자 프로그램 을 처음 시작하면 자동으로 우선SMS service 제공업 체에 접속하기 위하여 로그인하여 SMS 전송가능 통 화수를 확인한다. 이전에 설명한 바와 같이 원격제어 및 계측 장치의 $\mathrm{CDMA}$ 모뎀은 $\mathrm{TCP} / \mathrm{IP}$ 패킷 접속을 위한 고정 IP 주소를 갖고 있지 않기 때문에 회선접 속 방식을 사용해야 하지만, 이와 같은 경우 원격제 어 및 계측 서버 컴퓨터에 별도로 또 하나의 CDMA 모뎀 또는 PSTN 모뎀이 필요하다. 따라서 본 연구에 서는 별도의 다른 모뎀의 사용이 필요하지 않은 방법 으로 SMS 문자 메시지를 이용하는 방법을 사용하였 다.
$\mathrm{SMS}$ 메시지에 제어문자를 전송한 후 출력장치인 $\mathrm{LED}, \mathrm{LCD}, \mathrm{DAC}$ 의 'write' 기능은 메서드를 끝마치고 다시 프로그램 대기 상태로 돌아간다. 하지만 입력장 치인 DIP Switch, 온습도계, $\mathrm{ADC}$ 의 'read' 기능은 $\mathrm{MCS} 51$ 보드로 부터 상태정보를 원격 검침 서버 컴 퓨터로 전송해야 함으로 이때에는 TCP/IP 접속을 통 해 데이터를 받게 된다. 물론 이를 위해, 입력장치인 DIP Switch, 온습도계, $\mathrm{ADC}$ 의 'read'를 실행한 경우에 는 SMS 메세지에 사용자 프로그램이 실행중인 원격 제어 및 계측을 위한 사용자 컴퓨터의 IP주소와 Port 정보를 전송하게 된다. 이 정보를 이용하여 $\mathrm{CDMA}$ 모뎀은 Client가 되어 원격제어 및 계측 서버 컴퓨터 로 TCP/IP 패킷 접속을 시도하게 되고, 원격제어 및 계측 서버 컴퓨터는 서버역할을 하게 된다. TCP/IP 패킷 접속이 성공하게 되면 MCS51 보드로 부터 DIP Switch, 온습도계, $\mathrm{ADC}$ 의 상태정보를 받아 추출해내 어 각종 입출력장치의 화면 정보를 갱신한다. 만약 $\mathrm{TCP} / \mathrm{IP}$ 패킷망 접속이 실패할 경우 error 문구를 출력 하고 다시 버튼 입력 대기 상태로 돌아간다. 정상적 으로 정보를 추출했을 경우 TCP/IP 패킷망의 접속을 종료하고 다시 버튼 입력 대기 상태로 돌아간다.

사용자 컴퓨터의 IP주소 및 포트 정보는 기본적으 로 프로그램에 저장이 되어있으나 언제든지 사용자 프로그램에서 새로운 IP주소와 포트 정보로 저장할 수 있다. 또한 사용자는 화면에서 LED, DIP S/W, 온 습도계, $\mathrm{LCD}, \mathrm{ADC} / \mathrm{DAC}$ 중 원하는 기능을 위한 버튼 을 누르게 된다.

원격 제어 및 계측을 위한 사용자 프로그램에서 각 버튼은 void CSampleProjectDlg::OnBnClicked Button() 메서드로 구성되어 있으며 각 메서드에는 모 뎀에 전송할 제어문자 생성과 SMS 문자전송, TCP/IP 연결 등에 관한 실행이 정의 되어있다. LED On/Off 버튼을 클릭할 경우 원격제어 및 계측 서버 컴퓨터는 $\mathrm{CDMA}$ 모뎀에 "E1 E8"이란 제어문자가 담긴 SMS 문자를 전송하게 된다. E1 E8 명령은 4비트 LED의 On 4비트 Off 4비트에 각각 할당되어 있다. $\mathrm{LCD}$ 는 "L" 명령어 이후에 전송할 문자, 그리고 $\mathrm{DAC}$ 는 "DA" 이후에 전송할 전압 값을 원격제어 및 계측 장 치로 전송한다. 입력장치인 DIP S/W는 "D", 온습도 센서는 "T", 그리고 $\mathrm{ADC}$ 는 "AD"라는 명령에 원격 
검침 서버 컴퓨터의 주소를 함께 전송하여, 원격제어 및 계측장치에서 $\mathrm{CDMA}$ 모뎀으로 전송된 명령의 응 답을 수신하여 사용자 컴퓨터의 사용자 프로그램 화 면에 표시하며, 이와 같은 원격제어 및 계측을 위한 사용자 컴퓨터 응용 프로그램의 개발 결과는 아래 그 림13과 같다[10].

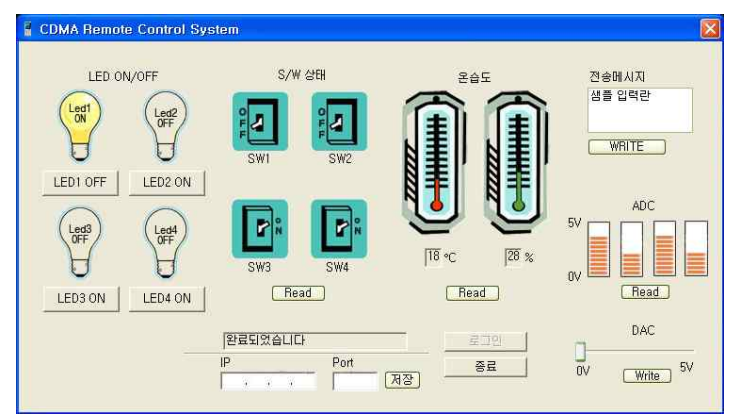

그림 13. 원격 제어 및 계측을 위한 사용자 프로그램

Fig. 13. User Application Program of Implemented Systems.

\section{$\mathrm{V}$. 결 론}

본 연구에서는 $\mathrm{CDMA}$ 모뎀을 이용하여 원격지에 서 언제든지 DIP Switch의 디지틀 입력장치, 온습도 센서, $\mathrm{ADC}$ 등의 입력장치의 상태정보를 획득하고, 또한 $\mathrm{LED}$ 의 디지틀 출력장치, 문자 $\mathrm{LCD}, \mathrm{DAC}$ 등의 출력장치를 제어할 수 있는 전체 시스템을 설계하고 이를 구현하였다. 원격 제어 및 계측을 위한 사용자 컴퓨터는 고정된 IP 주소를 보유하고 있기 때문에 원 격 계측 데이터를 사용자 컴퓨터에 전송하는 경우, 패킷통신을 통하여 데이터를 전송할 수 있지만, 반대 로 사용자 컴퓨터에서 원격 제어 명령을 원격 제어 및 계측 장치로 데이터를 전송할 경우에는 원격제어 및 계측 장치에서 사용되는 $\mathrm{CDMA}$ 모뎀의 고정 IP주 소가 없기 때문에 일반적인 패킷통신 방식을 사용할 수 없는 문제가 있다. 따라서 본 논문에서는 이와 같 은 문제를 해결하기 위하여 원격입출력장치에서 사 용자 컴퓨터사이의 통신에는 TCP/IP를 이용한 패킷 통신방식을, 그리고 사용자 컴퓨터와 원격입출력 사 이의 통신에는 SMS 방식을 사용하여 양방향 통신을 구현하였다. 이와 같은 제안의 방식은 오직 하나의 통신모뎀만을 사용하여 매우 효율적인 양방항 통신
을 구출할 수 있었다.

본 원격제어 및 계측장치의 하드웨어로 Telit社의 WM-800 CDMA 모뎀을 사용하였으며 MCS51 호환 으로 AT89C51 마이크로콘트롤러를 사용하였다. 또 한 여러 가지 다양한 분야에 응용이 가능하도록 다양 한 입출력 처리를 가상하여 출력장치로 $16 \times 4$ Line $\mathrm{LCD}$, 디지털 입력장치로 4 개의 DIP Switch, 디지털 출력장치로 4 개의 $\mathrm{LED}, \mathrm{I2C}$ 방식의 온습도센서, 4 채 널 8-bit $\mathrm{ADC}, 1$ 채널 8-bit $\mathrm{DAC}$ 를 인터페이스하였으 며 이를 요약하면 아래 표 1과 같다. 또한 원격제어 및 계측장치에서 사용자 응용프로그램 사이에는 AT 명령어를 이용한 TCP/IP 소켓을 이용한 클라이언트/ 서버 소켓프로그램을 구현하였으며, 그리고 사용자 컴퓨터와 원격 입출력장치사이에는 SMS 방식으로 양방향 통신프로그램을 구현하였다. 마지막으로 실 제 원격제어 및 계측을 위한 사용자 응용프로그램을 작성하여 위에서 제시된 각종 입출력장치의 실제 실 시간 실험을 통하여 양방향 데이터 통신 링크의 원할 한 통신을 확인하였으며, 그리고 사용자 응용프로그 램 화면을 통해 사용자가 원하는 동작을 구성된 원격 입출력장치가 정확하게 수행하여 동작하는 것을 확 인하였다.

표 1. 원격제어 및 계측 시스템의 사양

Table 1. Specification of Implemented Systems.

\begin{tabular}{|c|c|}
\hline 항목 & 사양 \\
\hline MCU & Atmel AT89C51 \\
\hline CDMA Modem & 4 channel \\
\hline Digital Input & 4 channel \\
\hline Digital Output & Sensirion SHT-11 \\
\hline 온/습도계 & $16 \times 4$ Line \\
\hline Display & 8bit, 4Channel \\
\hline DAC & 8bit, 1Channel \\
\hline ADC & \\
\hline
\end{tabular}

\section{감사의 글}

본 논문은 2011년도 한국기술교육대학교 교육연 구진흥비 지원에 의하여 연구되었음. 


\section{참 고 문 헌}

[1] Renjie Huang et al, "Real-World Sensor Network for Long-Term Volcano Monitoring," IEEE Transactions on Parallel and Distributed Systems, Vol.23, No.2, pp.321-329, Feb. 2012.

[2] Yan Zhang, Ansari, N. and Tsunoda, H., "Wireless telemedicine services over integrated IEEE 802.11/WLAN and IEEE 802.16/WiMAX networks," IEEE Wireless Communications, Vol.17, No.1, Feb. 2010.

[3] Jing Cai and Kun Liu, "Constructing a Remote Monitoring and Control System Based on 3G Mobile Networks," Int. Conf. on Wireless Communications, Networking and Mobile Computing(WiCom '09), pp.1-4, Sept. 2009.

[4] William Stallings, "Data and Computer Commu nications(7/E)," Prentice Hall, 2004.

[5] "CDMA Data Terminal" Data Book, Anydata, 2001.

[6] "CDMA Data Terminal" Data Book, Anydata, 2001.

[7] "Atmel AT89C21ED2" Data Book, Atmel, 2005

[8] http://www.keil.com

[9] http://www.smspia.com

[10] "Standard C++ Library Reference", Microsoft Visual Studio MSDN, 2010
이 명 의 (李明儀)

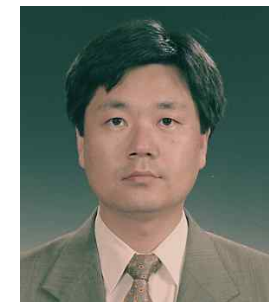

1985년 2월 : 인하대학교 전기공학 (공학사)

1987년 2월 : 인하대학원 기기 및 제어 (공학석사)

1991년 8월 : 인하대학원 기기 및 제어 (공학박사)

1995년 8월 : 현대전자 선임연구원

2004년 1월 2005년 1월 : U.C.Berkeley 객원교수 1995년 9월 현재 : 한국기술교육대학교 교수

관심분야 : 제어계측 시스템, 시스템 소프트웨어, 위성통신 시스템 